\title{
Geogenic Assessment of Water Quality Index for the Groundwater in Tiruchengode Taluk, Namakkal District, Tamilnadu, India
}

\author{
S. M. MAZHAR NAZEEB KHAN* and A. RAVI KUMAR
}

P.G \& Research Department of Chemistry, Jamal Mohamed College, Trichy-620020, Tamilnadu, India

drmazharjmc@gmail.com

Received 11 December 2012 / Accepted 13 January 2013

\begin{abstract}
The present work is aimed at assessing the water quality index (WQI) for the groundwater of Tiruchengode Taluk, Tamilnadu, India. It has been determined by collecting groundwater samples and subjecting the samples to a comprehensive physicochemical analysis. For calculating the WQI, the following 11 parameters have been considered viz, $\mathrm{pH}$, total hardness, calcium, magnesium, chloride, nitrate, sulphate, total dissolved solids, fluoride, alkalinity and dissolved oxygen. The results of analysis have been used to suggest models for predicting water quality. The analysis reveals that the groundwater of the area needs some degree of treatment before consumption and it also needs to be protected from the perils of contamination.
\end{abstract}

Keywords: Groundwater, Water quality index, Tiruchengode, Physicochemical analysis

\section{Introduction}

Groundwater is used for domestic, industrial water supply and irrigation all over the world. In the last few decades, there has been a tremendous increase in the demand for fresh water due to rapid growth of population and the accelerated pace of industrialization. Human health is threatened by unsanitary conditions through open drain carrying and disposing waste water into natural water bodies. Rapid urbanization, especially in developing countries like India, has affected the availability and quality of groundwater due to its overexploitation and improper waste disposal, especially in urban areas ${ }^{1}$.

The availability of a water supply adequate in terms of both quantity and quality is essential to human existence. The demand for water has increased over the years and this has led to water scarcity in many parts of the world. The situation is aggravated by the problem of water pollution or contamination. India is heading towards a freshwater crisis mainly due to improper management of water resources and environmental degradation. This leads to lack of access to safe potable water supply to millions of people. This freshwater crisis is already evident in many parts of India, varying in scale and intensity depending mainly on the time of the year ${ }^{2}$. 
Once the groundwater is contaminated, its quality cannot be restored, by stopping the pollutants from the sources. It therefore becomes imperative to regularly monitor the quality of groundwater and to device ways and means to protect it ${ }^{3}$. Water quality index(WQI) is one of the most effective tools to communicate information on the quality of water to the concerned citizens and policy makers. It thus, becomes an important parameter for the assessment and management of groundwater. WQI is defined as a rating reflecting the composite influence of different water quality parameters ${ }^{4}$.

The concept of WQI was firstly used by Horton, then it was developed and improved by Brown et al..$^{5-7}$. The development of WQIs for groundwater is described in the literature by various authors. Backman et al., present an index for evaluating and mapping the degree of groundwater contamination and test its applicability in southwestern Finland and Central Slovakia ${ }^{8}$. Soltan used WQI to indicate the water quality for ten well located near the DakhlaQasis in the Egyptian Western ${ }^{9}$. Stigter et al., used water quality indices for evaluating influence of agriculture activities on several key parameters of groundwater chemistry and potability ${ }^{10-11}$. Saeedi et al., developed groundwater quality index with identified places with best quality of drinking within west central of $\operatorname{Iran}^{12}$.

The objective of the present work is to discuss the suitability of groundwater for human consumption based on computed WQI values.

\section{Experimental}

The study area is situated at a distance of $45 \mathrm{~km}$ south-west of Salem and at a distance of $8 \mathrm{~km}$ from Sankaridurg, which is the nearest railway station. It lies between North Latitudes $11^{\circ} 20^{\prime}$ and $11^{\circ} 30^{\prime}$ and East Longitudes $70^{\circ} 50^{\prime}$ and $78^{\circ} 0^{\prime}$ 'with a total extent of $25.20 \mathrm{sq} \mathrm{km}$. This area experiences a tropical climate, with an average rainfall varies from $640 \mathrm{~mm}$ to $880 \mathrm{~mm}$. Mornings in general are more humid than the afternoons with the humidity exceeding $78 \%$ on an average. In the period from June to November the afternoon humidity exceeds $66 \%$ on an average. In the rest of the year the afternoons are drier, the summer afternoons being the driest.

The hot weather begins early in March, the highest temperature being felt in April and May. Weather cools down progressively from about the middle of June and December, the mean daily maximum temperature drops to $30.2^{\circ} \mathrm{C}$,

\section{Water sampling}

Twenty one groundwater samples were collected during December 2011 and February 2012 from seven different locations of Tiruchengode taluk of Namakkal district. Sampling stations are A:Anangur, B:Devanankurichi, C:Srinivasampalayam, D:Pirithi, E:Molasi, F: Eryamangalam and G:Patlur (3 samples from each locations). The samples were collected in clean $2 \mathrm{~L}$, polythene bottles without any air bubbles. The bottles were rinsed before sampling and tightly sealed after collection and labeled in the field. The temperatures of the samples were measured in the field itself at the time of sample collection.

\section{Analytical methods}

Analysis was carried out for various water quality parameters such as $\mathrm{pH}$, temperature, electrical conductivity, total dissolved solid, total hardness, total alkalinity, calcium, magnesium, chloride, biochemical oxygen demand, chemical oxygen demand, dissolved oxygen, nitrite and fluoride as per standard procedures recommended by APHA(1995) method. The water quality parameter values are in $\mathrm{mg} / \mathrm{L}$ except $\mathrm{pH}$ and $\mathrm{EC}$ in $\mu \mathrm{s} / \mathrm{cm}$.

In order to calculate WQI eight important parameters, $\mathrm{pH}$, dissolved oxygen (DO), total dissolved solids (TDS), electrical conductivity (EC), total hardness, calcium (Ca) ions, 
magnesium $(\mathrm{Mg})$ ions and total alkalinity have been selected. These parameters maximum contribute for the quality of the groundwater. The steps for WQI are given below

\section{Weightage}

For computing water quality index three steps are followed. In the first step, each of the 9 parameters has been assigned a weight (wi) according to its relative importance in the overall quality of water for drinking purposes. The maximum weight of 4 has been assigned to the parameter $\mathrm{pH}$, TDS and DO due to its major importance in water quality assessment. EC which is given weight of 1 . Second step, relative weight $(W i)$ is computed from the following equation:

$$
W i=w i / \sum w i
$$

Where $W i$ is the relative weight, $w i$ is the weight of each parameter. Calculated relative weight (wi) values of each parameters are also given in Table 1 . In the third step, a quality rating scale ( $q i)$ for each parameter is assigned by dividing its concentration in each water sample by its respective standard according to the guidelines laid down in the BIS and the result is multiplied by 100 :

$$
q i=(\mathrm{Ci} / \mathrm{Si}) \times 100
$$

Table 1. Relative weight of chemical parameters

\begin{tabular}{ccccccc}
\hline $\begin{array}{c}\text { S } \\
\text { No }\end{array}$ & $\begin{array}{c}\text { Chemical } \\
\text { Parameters }\end{array}$ & $\begin{array}{c}\text { Indian } \\
\text { Standards }\end{array}$ & $\begin{array}{c}\text { Weightage } \\
(\text { wi) }\end{array}$ & $\begin{array}{c}\text { Relative } \\
\text { Weight (Wi) }\end{array}$ & $\begin{array}{c}\text { Quality } \\
\text { Rating (qi) }\end{array}$ & $\begin{array}{c}\text { Sub Index } \\
(\mathrm{Si})\end{array}$ \\
\hline 1 & pH & $6.5-8.5$ & 4 & 0.173 & 94.11 & 16.28 \\
2 & EC & $<300$ & 1 & 0.043 & 1163.34 & 50.02 \\
3 & TDS & $500-2000$ & 4 & 0.173 & 79.15 & 13.69 \\
4 & TH & $300-600$ & 3 & 0.130 & 84.17 & 10.94 \\
5 & TA & $200-600$ & 3 & 0.130 & 101.17 & 13.15 \\
6 & Ca & $75-200$ & 2 & 0.086 & 81 & 6.96 \\
7 & DO & $>5$ & 4 & 0.173 & 72 & 12.45 \\
8 & Mg & $30-100$ & 2 & 0.086 & 88.34 & 7.59 \\
& & & wi=23 & Wi=0.994 & Wi=1763.28 & Si=131.08 \\
\hline
\end{tabular}

Where $q i$ is the quality rating, $C i$ is the concentration of each chemical parameter in each water sample in $\mathrm{mg} / \mathrm{L}$ and $\mathrm{Si}$ is the BIS (Bureau of Indian standards) water standard for each chemical parameter in $\mathrm{mg} / \mathrm{L}$ according to the guidelines of the BIS10500:1991. For computing the WQI, the SIi is first determined for each chemical parameter, which is then used to determine the WQI as per the following equation

$$
\begin{aligned}
S I i & =W i \times q i \\
W Q I & =\sum S I i
\end{aligned}
$$

$S I i$ is the Sub Index of $i^{\text {th }}$ parameter, $q i$ is the rating based on concentration of $i^{\text {th }}$ parameter. The computed WQI values are classified into five types "excellent water", "good water", "poor water" "very poor water" and "water unsuitable for drinking" as shown in Table 2.

Table 2. Water quality classification based on WQI value

\begin{tabular}{cc}
\hline WQI Value & Water Quality \\
\hline$<50$ & Excellent \\
$50-100$ & Good Water \\
$100-200$ & Poor Water \\
$200-300$ & Very Poor Water \\
$>300$ & Water Unsuitable for Drinking \\
\hline
\end{tabular}




\section{Results and Discussion}

In this chapter for the purpose of revealing the water quality of 21 samples covering the study area have been established by determining the physical and chemical characteristics as per standard methods. They have been listed systematically and represented in Table 3. The parameters viz., $\mathrm{pH}$ and total dissolved solids show the physical characteristics of the groundwater under the study area. The chemical characteristics of the groundwater under the study area are known by the parameters viz., total hardness, calcium hardness, magnesium hardness, fluoride, nitrate, chloride, sulfate, alkalinity and dissolved oxygen. Total hardness, calcium hardness \& magnesium hardness variations during the study period is presented in Figure 1.

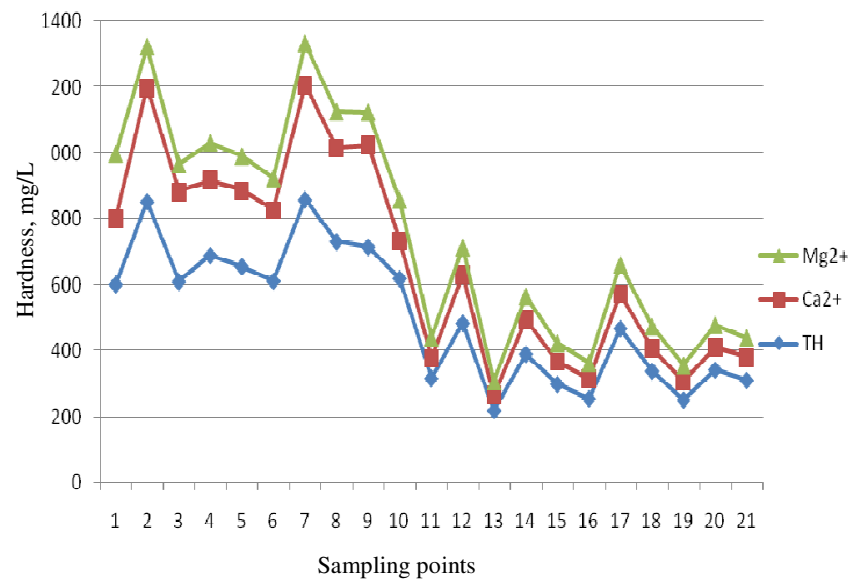

Figure 1. Total Hardness (TH), Calcium Hardness (Ca) and Magnesium Hardness $(\mathrm{Mg})$ variations during the study period

Dissolved oxygen, COD and BOD variations during the study period is presented in Figure 2. Fluoride, phosphate and nitrate variations during the study period are presented in Figure 3. Total alkalinity, chloride and sulphate variations during the study period are presented in Figure 4. pH, EC and TDS variations during the study period is presented in Figure 5. Summary of basic statistics for different water quality parameters are listed in Table 4.

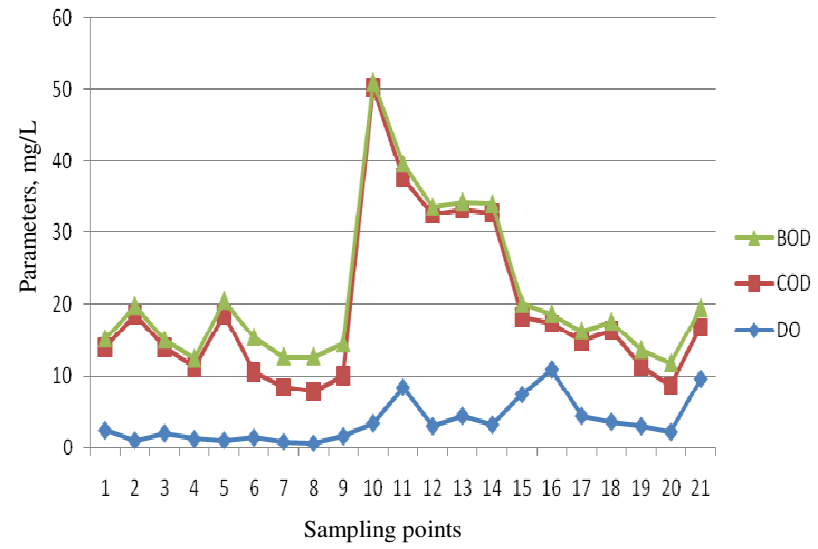

Figure 2. Dissolved Oxygen (DO), Biological Oxygen Demand (BOD) and Chemical Oxygen Demand (COD) variations during the study period 
Table 3. Physicochemical characteristics of groundwater samples of Tiruchengode block in Namakkal district in the month of December 2011 and February 2012

\begin{tabular}{|c|c|c|c|c|c|c|c|c|c|c|c|c|c|c|c|c|c|}
\hline $\begin{array}{l}\text { Sampling } \\
\text { Points }\end{array}$ & $\begin{array}{l}\text { Sampling } \\
\text { station }\end{array}$ & $\mathrm{pH}$ & EC & TDS & TH & TA & $\mathrm{Cl}^{-}$ & $\mathrm{SO}_{4}^{2-}$ & $\mathrm{Ca}^{2+}$ & $\mathrm{Mg}^{2+}$ & $\mathrm{NO}_{3}^{-}$ & DO & Temp & COD & BOD & $\mathrm{F}^{-}$ & $\mathrm{PO}_{4}^{3-}$ \\
\hline 1 & A-S1 & 8.0 & 4366 & 530 & 602 & 465 & 563.74 & 14.44 & 200.4 & 5.78 & 0.8 & 2.42 & 27.1 & 11.6 & 1.2 & 0.54 & 0.2 \\
\hline 2 & A-S2 & 8.0 & 6826 & 670 & 854 & 690 & 732.72 & 27.90 & 344.68 & 124.27 & 0.93 & 1.01 & 26.8 & 17.6 & 2 & .51 & 0.3 \\
\hline 3 & A-S3 & 8.1 & 6328 & 2090 & 610 & 840 & 692.96 & 4 & 4 & & 1.11 & 2.02 & 27.0 & 12.0 & 1.0 & 1.1 & 0.3 \\
\hline 4 & 1 & 7.9 & 6810 & 1700 & 690 & 675 & 792.36 & 5 & 5 & 1 & 1.27 & 1.21 & 26.0 & 10.0 & 1.2 & 1.1 & 0.5 \\
\hline 5 & & 8.1 & 5907 & 710 & 656 & 600 & 4 & 26 & 6 & & 1.05 & 1.01 & 26.3 & 17.6 & 1.9 & 95 & 0.3 \\
\hline 6 & & 7.9 & 5860 & 1710 & 612 & 615 & 2 & 1 & 3 & & 1.02 & 1.41 & 25.9 & 9.2 & 4.8 & 94 & 0.2 \\
\hline 7 & & 7.7 & 6415 & 5450 & 860 & 560 & 6 & & 9 & & 1.05 & 0.80 & .8 & 7.6 & 4.3 & 87 & 0.4 \\
\hline 8 & & 8.1 & 5189 & 1000 & 732 & 480 & 0 & 2 & & & 1.08 & 0.60 & 25.6 & 7.2 & 4.9 & 96 & 0.0 \\
\hline 9 & 3 & 7.9 & 5855 & 3100 & 716 & 550 & 4 & 19 & 1 & & 0.95 & 1.61 & 26.1 & 8.4 & 4.5 & .93 & 1.2 \\
\hline 10 & 1 & 8.2 & 2628 & 1974 & 620 & 835 & 4 & 27 & & 31 & 1.08 & 3.4 & 31.1 & 46.8 & 0.9 & 1.9 & 0.3 \\
\hline 11 & 2 & 8.7 & 3126 & 2388 & 316 & 150 & 6 & 31 & & & 0.6 & .4 & 30.7 & 29.2 & 2.1 & .1 & 0.5 \\
\hline 12 & 3 & 8.1 & 3180 & 2418 & 484 & 1080 & 57 & 29.84 & $14^{\prime}$ & 0 & 1.04 & 3.0 & 30.8 & 29.6 & 1.0 & 2.2 & 0.7 \\
\hline 13 & & 8.2 & 1483 & 1146 & 218 & 595 & 191 & 24 & & & 1.27 & 4.4 & 31.1 & 28.8 & .2 & .25 & 0.9 \\
\hline 14 & & 7.8 & 1061 & 848 & 390 & 555 & 130 & 16 & 10 & & 0.95 & 3.2 & 31.0 & 29.6 & .3 & 52 & 1.5 \\
\hline 15 & & 8.0 & 702 & 550 & 298 & 485 & & 18 & 68 & & 0.95 & 7.4 & 31.0 & 10.8 & 1.9 & 62 & 0.7 \\
\hline 16 & & 8.0 & 708 & 557 & 254 & 415 & 100.82 & 14.44 & 62 & 46 & 0.62 & 10.9 & 31.1 & 6.4 & 1.4 & 31 & 0.9 \\
\hline 17 & $\mathrm{~F}-\mathrm{S} 2$ & 7.8 & 1349 & 1088 & 468 & 595 & 281.16 & 21.17 & & 88.57 & 1.0 & 4.4 & 31.1 & 10.4 & 1.5 & 0.14 & 1.1 \\
\hline 18 & $\mathrm{~F}-\mathrm{S} 3$ & 7.9 & 1820 & 1439 & 338 & 705 & 285.42 & 18.29 & 69.73 & 65.45 & 0.90 & 3.6 & 31.1 & 12.8 & 1.2 & 0.51 & 0.7 \\
\hline 19 & G-S1 & 8.0 & 1841 & 1432 & 250 & 790 & 203.06 & 28.88 & 58.51 & 46.72 & 0.90 & 3.0 & 31.2 & 8.4 & 2.2 & 0.30 & 0.8 \\
\hline 20 & G-S2 & 7.9 & 1095 & 845 & 342 & 600 & 146.26 & 24.54 & 69.73 & 66.43 & 0.84 & 2.2 & 31.2 & 6.4 & 3.2 & 0.53 & 0.7 \\
\hline 21 & G-S3 & 7.9 & 743 & 588 & 310 & 475 & 97.98 & 13.95 & 70.54 & 58.42 & 0.84 & 9.6 & 31.2 & 7.2 & 2.7 & 0.36 & 0.8 \\
\hline
\end{tabular}

All the values are expressed in $\mathrm{mg} / \mathrm{L}$ except $\mathrm{pH}$ and $\mathrm{EC}(\mu \mathrm{S} / \mathrm{cm})$, Stations - A: Anangur, B: Devanankurichi, C: Srinivasampalayam,

D: Pirithi, E: Molasi, F: Eryamangalam and $G$ : Patlur 
Table 4. Summary of basic statistics for different water quality parameters*

\begin{tabular}{ccccc}
\hline Parameters & Min & Median & Mean & Max \\
\hline Temp & 25.00 & 30.00 & 28.71 & 31.00 \\
pH & 7.7 & 8.0 & 8.0 & 8.7 \\
EC & 702 & 3126 & 3490 & 6826 \\
TDS & 550 & 1432 & 1583 & 5450 \\
TH & 218 & 484 & 505 & 860 \\
TA & 150 & 595 & 607 & 1080 \\
Ca & 47 & 114 & 162 & 347 \\
DO & 0.6 & 3.0 & 3.6 & 10.9 \\
Mg & 41.65 & 85.22 & 88.34 & 195.78 \\
\hline
\end{tabular}

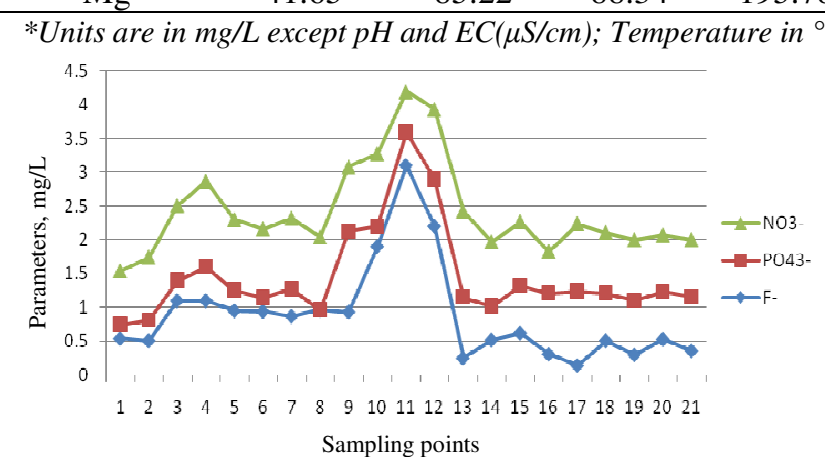

Figure 3. Fluoride $(\mathrm{F})$, Phosphate $\left(\mathrm{PO}_{4}{ }^{3-}\right)$ and -Nitrate $\left(\mathrm{NO}_{3}{ }^{-}\right)$variations

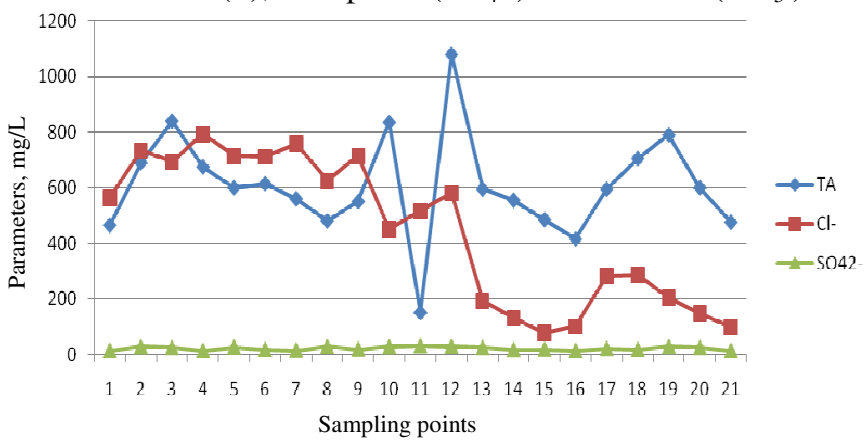

Figure 4. Total Alkalinity (TA), Chloride $\left(\mathrm{Cl}^{-}\right)$and Sulphate $\left(\mathrm{SO}_{4}{ }^{2-}\right)$ variations

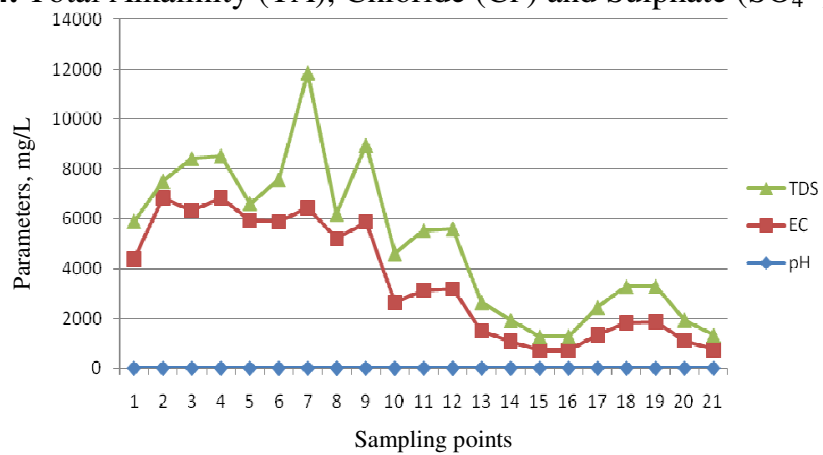

Figure 5. Electrical Conductivity (EC), Total Dissolved Solilds (TDS) and pH variations 


\section{Water quality index (WQI)}

The three steps of water quality index are:

\section{Step 1}

$w i=$ according to the relative importance (overall quality of water for drinking purpose). The maximum weightage of 4 has been assigned to the parameter $\mathrm{pH}$, TDS, DO and minimum weightage of 1 has been assigned for EC.

Step 2

$$
\text { Relative weight }(\mathrm{Wi}), \mathrm{Wi}=w i / \sum w i, \mathrm{Si}=\mathrm{Wi} \times q i, q i=(\mathrm{Ci} / \mathrm{Si}) \times 100
$$

Where $q i=$ Quality rating, $C i=$ concentration of each chemical parameter in each water sample in $\mathrm{mg} / \mathrm{L}, S i=$ Indian drinking water standard for each chemical parameter in $\mathrm{mg} / \mathrm{L}$. (according to BIS10500: 1991). Water quality index (WQI) $=$ sub index of the $i^{\text {th }}$ parameter.

Step 3

\section{Conclusions}

$$
W Q I=\sum S I i=131.08
$$

In the present investigation, an attempt was made to evaluate the groundwater quality of Tiruchengode Taluk, Namakkal district, Tamilnadu, India based on WQI. The Water Quality Index is a very useful and an efficient tool to summarize and to report on the monitoring data to the decision makers in order to be able to understand the status of the groundwater quality and to have the opportunity for better use in future as well. The overall view of the WQI (Table 1) of the present study zone shows a higher WQI. The overall WQI value in the study area was 131.08 which exceeded 100, the upper limit of drinking water. This value indicates poor water quality. It is observed that the water quality which is unfit for drinking. Necessary measures are to be taken to supply safe drinking water to the people living in the villages. The high value of WQI has been found to be mainly from EC, $\mathrm{pH}, \mathrm{TA}$ and TDS. The study reveals that the water quality is unfit for human consumption without treatment. Controlled waste disposal practice should be encouraged to minimize groundwater contamination. The study helps us to understand the quality of the water as well as to develop suitable management practices to protect the ground water resources.

\section{References}

1. Shivasharanappa, Srinivas P and Huggi M S, Int J Environ Sci., 2011, 2(2), 965-976.

2. Sundara Kumar K, Sundara Kumar P, Ratnakanth Babu M J and Hanumantha Rao C H, Int J Eng Sci Technol., 2010, 2(11), 6035-6046.

3. $\quad$ Khalid Hameed Lateef, Eur J Scic Res., 2011, 58(4), 472-481.

4. Ramakrishnaiah CR, Sadashivaiah C and Ranganna G, J Chem., 2009, 6(2), 523-530.

5. Brown R M, McClelland N I, Deininger R A and Tozer R G, Water Sewage Works, 1970, 117(10), 339-343.

6. Horton R K, J Water Pollution Control Federation, 1965, 37(3), 300-305.

7. Towards Cleaner Water 1975: Report of a Rivers Pollution Survey of Scotland Scottish Development Dept., ISBN: 0114913552

8. Backman B, Bodis D, Lahermo P, Rapant S and Tarvainen T, Environ Geol., 1998, 36(1-2), 55-64.

9. Soltan M E, Environ Monitoring Assessment, 1999, 57(2), 157-168.

10. Stigter T Y, Ribeiro L and Carvalho Dill A M M, J Hydrology (Amsterdam), 2006, 327(3-4), 578-591.

11. Stigter T Y, Ribeiro L and Carvalho Dill A M M, Hydrogeology J, 2006, 14(1-2), 79-99.

12. Saeedi Mohesn, Abessi Ozeair, Sharifi Farid and Meraji Hamed, DOI: 10.1007/s 10661-009-0837-5, 2009. 